GHANA JOURNAL OF DEPARTMENT OF HEALTH, PHYSICAL EDUCATION AND RECREATION, SPORTS AND DANCE (GJOHPERSD)

Volume 7 \& 8, Year 2014 \& 2015

A JOURNAL OF THE DEPARTMENT OF HEALTH, PHYSICAL EDUCATION AND RECREATION (HPER)

UNIVERSITY OF CAPE COAST

GHANA, WEST AFRICA 


\title{
OPINION OF PHYSICAL EDUCATION TEACHERS ON FACTORS INFLUENCING INTEGRATION OF PE INTO PRIMARY EDUCATION CURRICULUM IN OYO STATE
}

\section{Ibraheem, T. Olanrewaju, OJO, Ayorinde Victor \& Ibraheem, M. Oluwatoyin}

\author{
Department of Human Kinetics and Education, \\ University of Ilorin, Nigeria \\ infoiot@yahoo.com; ibraheem.to@unilorin.edu.ng \\ 08033380286
}

\begin{abstract}
This paper highlights the opinion of primary school Physical Education (P.E) teachers on the factors influencing integration of physical education into primary education curriculum in Oyo State. The paper tries to examine the meaning of curriculum as advanced by some scholars. It discusses the indispensable need for proper curriculum implementation. Moreover, an important focus of the paper pivots on the factors influencing the integration of Physical Education in primary school curriculum. Descriptive research design was used for this study. The population for this study consists the primary school teachers in Ibadan South West Local Government Area of Oyo State. 149 subjects were served with questionnaire to elicit responses on their opinions regarding factors influencing integration of P.E into primary education curriculum in Oyo State. Descriptive and inferential statistical analyses of chi square (X2) were used to test the hypotheses that were generated at a significant relationship of 0.05 alpha levels. The result of the findings revealed that, time allotted to P.E in primary schools have an influence on integration of P.E in the primary school curriculum. It also revealed that, availability of sport facilities and other infrastructure for P.E classes in primary schools have positive influence on integration of P.E in the primary school curriculum. It was also revealed in the paper that,
\end{abstract}




\title{
DIFFERENCES IN BODY ANTHROPOMETRY BETWEEN COMPETITIVELY EFFICIENT AND LESS EFFICIENT JUNIOR MALE HANDBALL PLAYERS
}

\author{
Adodo, S. M. \& Agwubike, E. O \\ Institute of Education \\ University of Benin \\ Benin City, Nigeria \\ e-mail:samado2g4@gmail.com,samuel.adodo@uniben.edu \\ Department of Human Kinetics and Sports Science \\ University of Benin \\ Benin City, Nigeria \\ e-mail: ellydike70@gmail.com
}

\begin{abstract}
This study was carried out to determine if differences existed in anthropometric and body composition characteristics between competitively efficient (above average) and less efficient (average) junior male handball players. A total of 106 junior male handball players participated in this study. The players were divided into two playing quality or performance groups of above average or (competitively efficient) $(n=26)$ and average or competitively less efficient $(n=80)$ levels. A combination of individual players' quality as determined subjectively by a consortium of national handball coaches and team ranking achieved at a championship were used to achieve this purpose. 22 anthropometric attributes were measured for each subject. Similarly, 6 body composition variables were estimated. The results showed that the above average players were better endowed morphologically than the average players particularly in the Longitudinal Skeleton Dimensionality (LSD), Transverse Skeleton Dimensionality (TSD) and Absolute Voluminosity of the Body (AVB) dimensions. The junior male players at both levels of performance were relatively homogenous in the Subcutaneous Fatty Tissue (SFT). However, the
\end{abstract}


A teacher is described as the professional who imparts knowledge, learning experiences at his or her disposal to stimulate, guide, direct and facilitate learners to acquire adequate mastery of the skills being imparted. Ajayi, (2004) defined a teacher as someone who causes learning to take place; someone who imparts knowledge, skills, values and attitudes to a group of learners. From the definitions, it is clear that, a teacher is one who helps the learners, often in a school, as well as in a family, religious and community setting.

Curriculum is learning experiences to which the learner is subjected, under the guidance of the school (Mezieobi, Fubura and Mezieobi, 2008). Alaezi (1989), submitted that, the school curriculum is at the heart of education, and so, to the extent which one can become dependent or independent is subjected to the level, the content and method of his or her education. Curriculum therefore could be said to be the bedrock of education, hence its functionality must be held in high esteem so as to achieve the aims as justified by the meaning of education.

This is referred to as education given in an institution for children above ages 6 to 11 plus. Primary education is made compulsory, universal and tuition free in the Nigerian public schools. All the subjects in the primary education curriculum, including physical and health education are offered as coresubjects (National Policy on Education, 2004). The term, curriculum implementation has been defined in different ways by various scholars. Babalola (2004) described curriculum implementation as: "the translation of the objectives of the curriculum from paper to practice". Mkpa (2005) defined curriculum implementation as: "the task of translating the curriculum document into the operating curriculum by the combined efforts of students, teachers and others concerned. Onyeachu (2008) viewed curriculum implementation as the process of putting all that have been planned as a curriculum document into classroom through the combined effort of the teachers, learners, school administrators, parents as well as interaction with physical facilities, instructional materials, psychological and social environments.

23 A Journal of the Department of Health, Physical Education and Recreation 
Opinion of Physical Education Teachers on Factors Influencing Intergration of PE into

Primary Education Curriculum in Oyo State

Ivowi (2004) defined curriculum implementation in a nutshell as; "the translation of theory into practice, or proposal into action". Curriculum implementation is viewed as: "putting the curriculum into work for the achievement of the goals for which the curriculum is designed (Garba, 2004). Critically looking at these definitions, it shows that, curriculum implementation is the interaction between the teachers, learners and other stake holders in education geared towards achieving the objectives of education. It is also evident from the above definitions that, curriculum implementation is indispensable. However, despite the need for proper implementation of the curriculum, there are certain factors militating against its successful implementation.

Physical Education as a teaching subject, has suffered neglect in Nigerian educational institutions in the past, as its scope was limited to exercises, physical drills or muscle building. In recent times, the Nigerian educators had agreed that, Physical Education/Human Kinetics be integrated into the school curriculum as a teaching subject. The Federal Government of Nigerian in its policy on education (National Policy on Education 1981, 2004) therefore, had stressed the need to direct the quality of instruction at all levels, towards the promotion of educational, physical and psychological health of all children among others. This will enable them become functional and productive members of the society. Thus, a functional Physical Education

Programme in all educational institutions must be vigorously pursued if appropriate skills, abilities and competences (both mental and physical) needed to equip the individuals to live in and contribute meaningfully to the development of the society must be achieved. It is in full realization of this assumption, that the Federal Government of Nigeria approved the inclusion of Physical and Health Education Curriculum into educational institutions at all levels.

Despite the importance of Physical education to man's day today's running, it is rather appalling that, there is a decline in the participation of Physical Education programme in educational institutions in Nigeria owing to many variables. Physical Education, like any other discipline in the school curriculum, has A Journal of the Department of Health, Physical Education and Recreation 
many challenges in participation towards achieving its set goals and objectives in schools. Generally, certain problems cut across all educational institutions. The abolition of Teachers' Grade II

Colleges in Nigeria, where foundation of Physical Education, as a discipline and course of study was laid, is identified as a determinant in the declining profile of the programme in schools in Nigeria (Isaac \& Johnson, 2014). Physical Education facilities and equipment are expensive, thus requiring a large sum of money to procure. Unfortunately, Physical Education and sport facilities as well as equipment are grossly inadequate for teaching of the subject in most Nigeria, educational institutions. Most institutions do not have minimum standard of facilities and equipment. Even what is available in the universities where the basic skills needed to teach the subject is required, it is grossly inadequate relatively. Cultural and religious taboos in some communities, inhibit children from exposing some parts of their bodies (their hand, legs and thighs) during Physical Education practical lessons. Such restrictions normally have detrimental effects on the effective participation in Physical Education.

Physical Education as a lesson, is on the timetable of almost all the schools, but it is unfortunate that, there are no Physical Education teachers to handle the lessons. The Teachers' Grade II programme has been cancelled. Though, it is the government policy that, the least qualification for primary school teachers should be Nigerian Certificate in Education (N.C.E). It is only in private primary schools that one can find N.C.E and University degree holders and this is because, jobs are very difficult to come by in the country presently (Edim, Emeribe \& Akah 2010). There is a general belief that, physical education in schools is dominated by team games and that, too little time is spent in more individual-based physical activities (Halbert \& MacPhail,

2005).The result is that, too much emphasis is placed on performance and winning, rather than on learning and individual improvement. Ross and Gilbert (1985) noted that, although there was an upward trend across age groups and that, only a small amount of the physical education curriculum was devoted to 25 A Journal of the Department of Health, Physical Education and Recreation 
Opinion of Physical Education Teachers on Factors Influencing Intergration of PE into Primary Education Curriculum in Oyo State participation in lifetime physical activities. The reasons for this may include large class sizes, inadequate facilities and a lack of teacher confidence in teaching all the areas in the curriculum, resulting in a neglect of other strands of the physical education curriculum.

Economic and social class, gender and tribe are interconnected because; they limit Physical Education and sports participation among students from low-income background. Opportunities to be accepted into the academic discipline were very limited for Physical Education and sports. According to Adedeji (1985 and 2001), few Physical Education specialists in the past, achieved fame and fortune in sports, but because of perceived obstacles to achievement like other careers, many young specialists in contemporary society see Physical Education and sports participation as an occupation in its glorious height only. In relation to social class, employment, economy and income, the changes that have occurred in recent years, seem to be most visible in relation to employment. Unfortunately, students' enrollment for Physical Education in the tertiary institutions in Nigeria has declined dramatically (Henderson, 1996). The few textbooks available on Physical Education and sports written by Nigerian authors emphasize mainly games and sports skills, neglecting other aspects of the programme (Isaac \& Johnson, 2014).

In addition to the above discussed problems affecting the integration of physical education into primary school curriculum, the following factors also adversely affect its success:

Inadequate funding of the education sector has been a major challenge facing the sector. Researchers, Aina (2002), Durosaro (2006), Amadi (2007); Balogun (2010) lamented over the inadequacy of fund in the education sector. It is not an understatement to note that, the Nigerian government, over the years, as reported by Isaac and Johnson, (2014) has not been meeting the UNESCO recommendations of $26 \%$ of the total budgetary allocation to the education sector. For example, the allocation to Education in the National Budget for 2003, 2004 and 2005 were $7 \%, 12 \%$ and $11 \%$ (FRN 2005). According to Akindutire (2001), the poor funding of the teacher education since A Journal of the Department of Health, Physical Education and Recreation 
the 1980s has become a cause of worry to educationists as it affects the merits and standard of the certificates awarded to education graduates. Professionalization of the teachers' profession would give the profession a better image, thus making the code of ethics respected.

In making a professional teaching qualification mandatory, government should make it compulsory for all in the teaching jobs, at all levels, in order to acquire teaching qualifications. Government should give another deadline within a convenient time-frame to ensure that, by 2015, all teachers would have become professionals. This is because the 2006 deadline as seen in the TRC Act had failed, 2006 had come and gone and nothing much had been done to ensure that, all teachers are professionalized. Thanks to some state Governments in Nigeria that gave, a salary differential in the payment of the Teachers' Salary Structure (TSS). While teachers with educational background enjoy $27.5 \%$, those without education certificate enjoy $12.5 \%$ (Isaac \& Johnson, 2014). There is also the need for improvement in the level of the infrastructural facilities in schools. This however, depends to a large extent, on the level of funding made available to the system. Ibukun (2004) advocated for modern educational gadgets; like computers, modern instructional materials, packages as well as other practical facilities to be consciously introduced into the teacher education programme. It must be noted that, no programme, no matter how well intended, can succeed if adequate infrastructural facilities are not provided for implementation. Ibukun (2014) further explained that more time should be provided for practical work before students are certified as teachers. There is the need to review upward, the twelve weeks of internship for education students in the university. To provide sound teacher education in future, the present curriculum need to be reviewed so as to provide more time for students in the practical aspect of teaching before certificates are awarded to them as qualified teachers. The time allotted for the teaching of Physical Education in primary schools should also be reviewed up. More time should be given for teaching the subject as only then can a meaningful impact be felt.

27 A Journal of the Department of Health, Physical Education and Recreation 
Opinion of Physical Education Teachers on Factors Influencing Intergration of PE into

\section{Purpose of the Study}

Primary Education Curriculum in Oyo State

This study attempts to describe the opinion of PE teachers on factors influencing integration of $\mathrm{PE}$ into primary education curriculum in Oyo state using the Ibadan Municipal Grammar School \& St. Michaels Primary School in the Ibadan South West Local Government Area as a case study with a view to proffering solutions, to the lingering problem of decline in participation in Physical Education.

\section{Statement of the Problem}

The rocket-speed decline in the rate of children's participation in physical education is an important issue that needs to be addressed to ensure continuity of the subject. Pupils' perception is that, physical and health education is an optional subject, hence the commitment of a nonchalant attitude towards participation in it. The understanding of elective is that, the subject is optional. It is likely that, greater percentage of pupils would drop any subject which is made optional. There is a need for P.E to be made a core subject at all levels of education in Nigeria. Several researchers including Edim, Emeribe and Akah (2010) have tried to highlight the need for the promotion of physical education as a core subject in Secondary Schools, but much has not been done on primary schools in the Ibadan South-West Local Government Area of Oyo State, hence the need for this research.

\section{Research Questions}

For the purpose of this study, the following research questions were formulated in order to carry out the research:

1) Will the time allotted to P.E in primary schools have any influence on the integration of P.E in the primary school curriculum?

2) Will the availability of funds have any influence on integration of P.E into the primary school curriculum?

3) Will availability of sport facilities for P.E practical classes in primary schools have any influence on integration of P.E in the primary school curriculum? 
Olanrewaju et al

4) Will disseminating information on the need for participation in PE by the government have any influence on integration of P.E in the primary school curriculum?

\section{Hypotheses}

1) Time allotted to P.E in primary schools will have an influence on integration of P.E in the primary school curriculum.

2) Availability of sport facilities for P.E practical classes in primary schools will not have any influence on integration of P.E in the primary school curriculum.

3) Availability of funds will not have any influence on integration of P.E into the primary school curriculum.

4) Dissemination of information on the need for participation in PE by the government will have a positive influence on integration of P.E in the primary school curriculum.

\section{Methodology}

The design for the study is based on survey method. Bobade (2003), described survey method of research as a brand of descriptive research in as much as it deals with the present description of variables, situations, events, phenomena, etc and the relationships between them. Bobade (2003) further said, it involves the systematic study of a population on a particular phenomenon exhibited by the population.

\section{Population and Sampling Procedure}

The sampled population comprised of 159 primary school teachers from the eight (8) public primary schools available in Ibadan South West Local Government Area of Oyo State, i.e the St. Michael's African Primary Schools 1 to 7 and Ibadan Municipal Grammar School. The population was purposively and randomly sampled. The total target population therefore was 149 subjects, using the random number table as provided by The Research Advisors (2006) to represent the 159 primary school PE teachers available in the Ibadan South West Local Government Area of Oyo State. 


\section{Research Instrument}

Primary Education Curriculum in Oyo State

The research instrument for data collection is the questionnaire designed by the researcher to collect information on opinion of $\mathrm{PE}$ teachers on factors influencing integration of $\mathrm{PE}$ into primary education curriculum in Oyo State. A total of 149 questionnaire were distributed to the respondents by the investigator with the aid of three research assistants and the filled-in questionnaire were also collected immediately after the respondents had completed filling them.

\section{Data Analysis}

The information collected through the questionnaire was subjected to inferential statistical analysis of chi square $\left(\mathrm{X}_{2}\right)$ in order to test the hypotheses for significant relationship of 0.05 alpha level.

Results of finding: Table 1: Contingency and Chi-Square table on Time \& Curriculum Integration.

\begin{tabular}{lccccccccc}
\hline Item & SA & A & D & SD & $\begin{array}{l}\text { ROW } \\
\text { TOTAL }\end{array}$ & df & $\begin{array}{l}\text { Cal. } \\
\mathbf{X}^{\mathbf{2}}\end{array}$ & $\begin{array}{l}\text { CRITICAL } \\
\text { VALUE }\end{array}$ & DECISION \\
\hline 1 & 8 & 16 & 92 & 33 & 149 & & & & \\
2 & 97 & 35 & 8 & 9 & 149 & 6 & 12.592 & 264.73 & Fail to reject \\
3 & 88 & 52 & 5 & 4 & 149 & & & & \\
\hline TOTAL & 193 & 103 & 105 & 46 & 447 & & & & \\
\hline
\end{tabular}

Alpha value 0.05

Table 1 revealed that, the calculated chi square $\left(\mathrm{X}_{2}\right)$ value of 12.592 is lower than the critical value of 264.73 at 0.05 level of significance and degree of freedom (df) of 6. Therefore, we fail to reject the Null hypothesis. Consequent to the Accepted hypothesis, time allotted to P.E in primary schools will have an influence on integration of P.E in the primary school curriculum. 
Olanrewaju et al

Table 2: Contingency and Chi-Square table on Facilities \& Curriculum Integration.

\begin{tabular}{lccccccccc}
\hline ITEM & SA & A & D & SD & $\begin{array}{l}\text { ROW } \\
\text { TOTAL }\end{array}$ & df & $\begin{array}{l}\text { CAL. } \\
\mathbf{X}^{2}\end{array}$ & $\begin{array}{l}\text { CRITICAL } \\
\text { VALUE }\end{array}$ & DECISION \\
\hline 1 & 13 & 12 & 28 & 96 & 149 & & & & \\
2 & 4 & 19 & 42 & 84 & 149 & 6 & 12.592 & 11.61 & Rejected \\
3 & 9 & 14 & 28 & 98 & 149 & & & & \\
& & & & & & & & & \\
\hline TOTAL & 26 & 45 & 98 & 278 & 447 & & & &
\end{tabular}

$$
\alpha 0.05
$$

Table 2 revealed that, the calculated chi square $\left(\mathrm{X}_{2}\right)$ value of 12.592 is greater than the critical value of 11.61 at 0.05 level of significance and degree of freedom (df) of 6 . Therefore, the hypothesis was Rejected. Consequent to the rejected hypothesis, availability of sport facilities and other infrastructure for P.E classes in primary schools will have positive influence on integration of P.E in the primary school curriculum.

Table 3: Contingency and Chi-Square table on Funds \& Curriculum Integration.

\begin{tabular}{llllllllll}
\hline ITEM & SA & A & D & SD & $\begin{array}{l}\text { ROW } \\
\text { TOTAL }\end{array}$ & df & $\begin{array}{l}\text { CAL. } \\
\mathbf{X}^{\mathbf{2}}\end{array}$ & $\begin{array}{l}\text { CRITICAL } \\
\text { VALUE }\end{array}$ & DECISION \\
\hline 1 & 3 & 9 & 49 & 88 & 149 & & & & \\
2 & 5 & 6 & 46 & 92 & 149 & $\mathbf{6}$ & $\mathbf{1 2 . 5 9 2}$ & $\mathbf{4 . 8}$ & Rejected \\
3 & 4 & 6 & 36 & 103 & 149 & & & & \\
\hline TOTAL & 12 & 21 & 131 & 283 & 447 & & & &
\end{tabular}

31 A Journal of the Department of Health, Physical Education and Recreation 
Opinion of Physical Education Teachers on Factors Influencing Intergration of PE into Primary Education Curriculum in Oyo State $\alpha 0.05$

Table 3 revealed that, the calculated chi square $\left(\mathrm{X}_{2}\right)$ value of 12.592 is greater than the critical value of 4.8 at 0.05 level of significance and degree of freedom (df) of 6 . Therefore, the hypothesis was Rejected. Consequent to the Rejected hypothesis, availability of funds will have a positive influence on integration of P.E into the primary school curriculum.

\section{Table 4: Contingency and Chi-Square table on government policy \& Curriculum Integration.}

\begin{tabular}{|c|c|c|c|c|c|c|c|c|c|}
\hline $\begin{array}{l}\text { ITEM } \\
\end{array}$ & SA & $\mathbf{A}$ & D & SD & $\begin{array}{l}\text { ROW } \\
\text { TOTAL }\end{array}$ & $\overline{d f}$ & $\begin{array}{l}\text { CAL. } \\
\text { X }^{2}\end{array}$ & $\begin{array}{l}\text { CRITICAL } \\
\text { VALUE }\end{array}$ & DECISION \\
\hline 1 & 6 & 12 & 42 & 89 & 149 & \multirow{5}{*}{6} & \multirow{5}{*}{12.592} & \multirow{5}{*}{224.1} & \multirow{5}{*}{$\begin{array}{l}\text { Fail } \\
\text { reject }\end{array}$} \\
\hline 2 & 54 & 60 & 24 & 11 & 149 & & & & \\
\hline & & & & & & & & & \\
\hline 3 & 4 & 5 & 35 & 106 & 149 & & & & \\
\hline TOTAL & 64 & 77 & 101 & 205 & 447 & & & & \\
\hline
\end{tabular}

Table 4 revealed that, the calculated chi square $\left(\mathrm{X}_{2}\right)$ value of 12.592 is less than the critical value of 224.1 at 0.05 level of significance and degree of freedom (df) of 6. Therefore, we fail to reject the hypothesis. Consequent to the Accepted hypothesis, dissemination of information on the need for participation in PE by government will have a positive influence on integration of P.E in the primary school curriculum.

\section{Discussion of Findings}

The result from tested hypothesis 1 shows that consequent to the Accepted hypothesis, time allotted to P.E in primary schools will have an influence on integration of P.E in the primary school 
curriculum. This is in line the view of Ibukun (2004) that more time should be provided for practical work before students are certified as teachers. There is the need to review upward, the twelve weeks of internship for education students in the university. To provide sound teacher education in future, the present curriculum need to be reviewed so as to provide more time for students in the practical aspect of teaching before certificates are awarded to them as qualified teachers. The time allotted for the teaching of Physical Education in primary schools should also be reviewed up. More time should be given for teaching the subject as only then can a meaningful impact be felt.

The result from hypothesis 2 revealed that consequent to the rejected hypothesis, availability of sport facilities and other infrastructure for P.E classes in primary schools will have positive influence on integration of P.E in the primary school curriculum. The above revelation is in support of Ibukun (2004) when he advocated for modern educational gadgets like computers, modern instructional materials, packages as well as other practical facilities to be consciously introduced into the teacher education programme.

The result from hypothesis 3 revealed that consequent to the Rejected hypothesis, availability of funds will have a positive influence on integration of P.E into the primary school curriculum. This finding is further buttressed by Akindutire (2001) that, the poor funding of the teacher education since the 1980s has become a cause of worry to educationists as it affects the merits and standard of the certificates awarded to education graduates. The result is further supported by Aina (2002), Durosaro (2006), Amadi (2007) and Balogun (2010) where they all lamented over the inadequacy of fund in the education sector.

The result from hypothesis 4 shows that consequent to the accepted hypothesis, dissemination of information on the need for participation in PE by government will have a positive influence on integration of P.E in the primary school curriculum. The finding is supported by the submission of Bucher (1979) that various government levels need to introduce Bills and enact laws through legislative arms to protect students and consumers. Also 33 A Journal of the Department of Health, Physical Education and Recreation 
Opinion of Physical Education Teachers on Factors Influencing Intergration of PE into Primary Education Curriculum in Oyo State appropriate information and guidelines should be set forth to assist students and those that engage in ohysical activities.

\section{Conclusion}

Based on the findings of this study, the following conclusions were drawn:

1. Time allotted on subject time table to P.E in primary schools will have an influence on integration of P.E in the primary school curriculum.

2. Availability/non availability of sport facilities for P.E practical classes in primary schools will have influence on integration of P.E in the primary school curriculum.

3. Availability/non availability of funds will have influence on integration of P.E into the primary school curriculum.

4. Dissemination of information on the need for participation in PE by the government will have a positive influence on integration of P.E in the primary school curriculum.

\section{Recommendations}

Based on the above observations, it is imperative to state that, integration of physical education into primary school curriculum in Nigeria needs to be given close attention by physical education experts and all stakeholders including the government. It is in view of this that, the following recommendations are made:

1. More time should be allotted to teaching PE in primary schools than what is it presently.

2. Adequate and functional sport facilities for P.E practical classes in primary schools should be made available by government and stakeholders.

3. Funds should be made available and such funds must be used only for the purpose intended for facilitating the smooth running of the school, especially regarding the effective teaching of PE.

4. Public enlightenment should be done by government as well as all stake holders on the need for participation in PE by all and sundry, especially with a view to eradicating the 
Olanrewaju et al

idea that, participating in PE practical classes and sports would promote nudity.

\section{References}

Adedeji, J. A. (1985). Teaching of Physical and Health Education.

(1st Ed). lbadan: Westbooks Publishers Limited

Adedeji, J. A. (2001). Equality of Opportunity: The Evolution of Democracy in Physical Education and Sports Ibadan: A Valedictory Lecture, University of Ibadan. Eden Prints.

Aina, O.I. (2002). Alternative modes of financing higher education in Nigeria and the implications for university governance. Africa Development, 27(1\&2): 236 - 262.

Ajala, J. A., Amusa, L. O. \& Sohi, S. A. (2002). Physical Education. Lagos: Macmillan Publishers.

Ajayi, I.A. (2004). Social science method. Ado-Ekiti: Green Line Publishers.

Akindutire, I.O. (2001). The teaching profession. Lagos: Universal Publishers.

Alaezi, O. (1989). The Nigerian new school curriculum: Issues and insights. Jos: Ehindeyo (Nig) Ltd.

Amadi, M.N. (2007). Funding initiatives in higher education. in J. B. Babalola, G. O. Akpa, A. O. Ayeni, S. O. Adedeji (Eds) Access, Equity and Quality in Higher Education. NAEAP Publications. 543-554.

Babalola, V. O. (2004). Resources materials in the implementation of curriculum in the $21^{\text {st }}$ century in A. O. K.Noah, D. O. Shonibare, A. A. Ojo \& T. Olujuwon, (Eds); Curriculum implementation and professionalizing teaching in Nigeria. Lagos: Central Education Services

Balogun, A.M. (2010). Challenges of higher education in Nigeria: A manager's perspective. Being a paper presented at the maiden edition of the Faculty of Education Annual Lecture Series, University of Ado-Ekiti, March 22nd.

Bobade, M.O. (2003). Research Methodology; Fundamental Approach. Revised Ed. Ibadan: Waleswealth.

35 A Journal of the Department of Health, Physical Education and Recreation 
Opinion of Physical Education Teachers on Factors Influencing Intergration of PE into Primary Education Curriculum in Oyo State

Bucher, C. A. (1979). Foundations of Physical Education. (8th Ed.). The CV Mosby Company. London.

Durosaro, D.O. (2006). Teacher education in Nigeria: Past, present and future challenges. The Pacesetter: J. Oyo State College Educ. 13 (1): 44-54.

Edim, M. E., Emeribe, V. C. \& Akah, L. U. (2010). The place of adapted physical education in special education curriculum, in T. Ajobiewe \& P. I. Osuorji (Eds). New perspectives in special needs education for sustainment development. Ibadan: Glory-Land Publishing Company.

Federal Ministry of Education (1981): National Policy on Education. Lagos: Federal Government Press.

Federal Ministry of Education (2004): National and Policy on Education (4th Ed). Lagos: Federal Government Press.

Federal Republic of Nigeria (2004). National Policy of Education. Lagos: National Educ. Res. Dev. Council.

Federal Republic of Nigeria (2005). Federal Republic of Nigeria in Collaboration with International Labour Organization (ILO) action programme as education 2004-2005: Teachers for the future: meeting teacher shortages to achieve education for all. Nigeria: National Policy Brief.

Garba, M. (2004). The critical role of education resource of curriculum implementation in A. O. K. Noah, D. O.Shorribare, A. A. Ojo, \& T. Olujuwon, (Eds); Curriculum implementation and professionalizing teaching in Nigeria. Lagos: Central Education Services.

Halbert ,J., \& MacPhail, A.(2005). Physical Education in Ireland. In: Puhse U, Gerber M, editors. International Comparison of Physical Education. Concept - Problems - Prospects: Aachen: Meyer \& Meyer Verlag; 2005. p. 380-399.

Henderson, S. B., (1996). Physical Education and Sports: An occupational Perspective (9th ed.). London: C.V. Mosby Company. 